\title{
Does Innovation Affect Company Performance? Exploring the Mediation Effects of Management Accounting Information Systems
}

\author{
Desrir Miftah, Julina \\ Departement of Accounting, State Islamic University of Sultan Syarif Kasim Riau \\ Jalan HR. Soebrantas Km. 15 No. 155, Panam, Kec. Tampan, Kota Pekanbaru, Riau, 28293
}

\begin{tabular}{l}
\hline A R T I C L E I N F O \\
\hline Keywords: \\
Company performance, \\
Innovation, \\
Management accouting information \\
systems \\
\\
Kata Kunci: \\
Kinerja perusahaan, \\
Inovasi, \\
Sistem Informasi Akuntansi Manajeme
\end{tabular}

\author{
A B S T RACT
}

This study attempt to determine the direct effect of innovation on company performance and its indirect effect through Management Accounting Information Systems (MAIS) as an mediating/intervening variable. Samples were managers in the manufacturing industry that produces Crude Palm Oil (CPO) operating in Riau Province. Data collected through questionnaires and processed using SEM-PLS. The results found that innovation affects firm performance. Management Accounting Information Systems mediates the effect of innovation and firm performance. Research on MAIS as intervening variable in the palm oil industry was first carried out especially in Indonesia. Innovations made by company through a good Management Accounting Information System will improve the performance of CPO producing company.

\section{SARI PATI}

Penelitian ini dilakukan untuk mengetahui pengaruh langsung inovasi terhadap kinerja perusahaan dan pengaruh tidak langsungnya melalui Sistem Informasi Akuntansi Manajemen (SIAM) sebagai variabel mediasi/ intervening. Sampel adalah para manajer pada industri manufaktur penghasil Crude Palm Oil (CPO) yang beroperasi di Provinsi Riau. Pengumpulan data dilakukan melalui kuesioner dan diolah menggunakan SEM-PLS. Hasil penelitian menemukan bahwa inovasi mempengaruhi kinerja perusahaan. Sistem Informasi Akuntansi Manajemen dapat memediasi pengaruh inovasi terhadap kinerja perusahaan. Penelitian SIAM sebagai intervening variable dalam industri kelapa sawit pertama kali dilakukan khususnya di Indonesia. Inovasi yang dilakukan perusahaan melalui Sistem Informasi Akuntansi Manajemen yang baik akan meningkatkan kinerja perusahaan penghasil CPO.

(C) 2020 IRJBS, All rights reserved.

Corresponding author:

desrir.miftah@uin-suska.ac.id 


\section{INTRODUCTION}

Global competition nowadays is a challenge that must be faced by every organization. Rapid technological change in an organizational environment is one of them. Management functions are required to professionally process resources to improve organizational performance. Performance measurement is needed so that management can make strategic decisions related to achieving the expected performance.

The Balanced Scorecard (BSC) by Kaplan and Norton, (2001) is one of the multidimensional performance measures. BSC covers non-financial and financial performance consisting of four perspectives. This perspective is a financial perspective that results from three other perspectives, namely the customer perspective that shows customer performance, the internal perspective of business processes that show the performance of internal processes, and the learning and growth perspective. However, to achieve comprehensive performance, financial, and non-financial performance must jointly be a concern for management (Davis \& Cobb, 2010).

The competitive advantage is very important for every organization to win the competition. One way is by innovation. Innovation is a process that utilizes skills and resources to achieve maximum performance. Innovation can be in the form of developing new products by building new production systems and operations to meet customer needs (Jones, 2013). The impact of innovation on company performance (customer satisfaction, productivity, and technological competitiveness) has been demonstrated by Terziovski (2002), thus making organizations superior in competition.

Contingency Theory supports the relationship between innovation and firm performance by stating that the design of an organization will be effective only under certain conditions (Otley, 1980). If conditions are different, then the design is also different, among others, it can be seen from the type of industry, regional/geographical differences. Certain innovation strategies are one of the contingent factors influencing financial performance in conditions of tight competition.

Management needs reliable information to make decisions. An accurate and reliable accounting system must have a broad scope, timeliness, aggregation, and integration criteria. Management accounting information systems provide information for management to make better decisions, and this requires information technology (Abernethy \& Guthrie, 1994). Every strategy, including an innovation strategy, requires specific information. Innovation strategies affect the design of management accounting information systems. There is a strong interaction between business strategy and management accounting information systems (Abdallah, 2014).

This research was conducted in the manufacturing sector of the Palm Oil Company which produces Crude Palm Oil (CPO) in Riau Province. Riau Province has the largest oil palm plantations in all of Indonesia, land use for oil palm plantations in 2014 reached 2.3 million hectares. The total land area is equivalent to 25 percent of the total area of Indonesian oil palm plantations with the amount of CPO production in Riau Province recorded at $7,045,632$ tons and the operational cooperation factory recorded 1,761,408 tons. Oil palm plantations supported by government policies that continue to encourage the opening of new land for plantations that began in 1980. At that time, the area of plantation land reached 294,560 hectares with CPO production of 721,172 tons. The development of oil palm plantations is directly proportional to the development of oil palm mills. The spread of cooking oil factories in Indonesia in 2015 showed North Sumatra to be the region with the largest population of cooking oil factories in Indonesia, covering $30.46 \%$ of the total number of cooking oil factories in the country and followed by Riau with 24.83\% ("PerkebunanSawit", 2015). 
Facing competitive competition, palm oil mills are also required to produce a good performance, both financial and non-financial performance. For this reason, the company must have a competitive advantage to excel in global competition. Competitive advantage can be achieved by having the right competitive strategy. There are various strategies used by the company, including a typology of prospector strategies and differentiation strategies proposed (Porter, 2008), emphasizing their competition through the innovation process and sustainable innovation strategies proposed (Terziovski, 2002).

Increased global competition and advances in information technology are very important for palm oil manufacturing companies to implement an innovation strategy supported by an integrated MAIS to achieve better company performance. Hence, this study attempts to prove that MAIS mediate the relationship between innovation and company performance. This research is expected to contribute to the development of knowledge related to company performance mediated by MAIS. Company management should pay attention to innovation strategies, MAIS in making business decisions related to company performance, thus leading to competitive advantage.

\section{Company Performance}

The company's performance shows the company's ability to generate profits or returns on the resources invested. According to Subramanyam and Wild (2010), return on capital investment is an important indicator of the company's strength in the long run. Helfert (1996) explains that company performance is the result of many individual decisions made continuously by management. This management decision is related to company strategies and systems that support management decisions, for example, management accounting information systems. The company's performance in general and in competitive advantage is a measure of the level of success and development of the company. Measurements of investment returns, growth, volume, profits, and labor in general companies are carried out to determine the company's performance (Jennings \& Beaver, 1997). Corporate management accounting practices can significantly influence opportunities for success and survival in a turbulent environment (Chenhall \& Morris, 1986; Chenhall, 2003; Van der Stede et al, 2006; Langfieldsmith, 2007), and increased understanding such as how these practices affect company performance is important for management effectiveness.

\section{Innovation}

Innovation is defined as a process in an organization about how to utilize skills and resources to develop new products and or services or to build new production systems and operations to meet customer needs (Jones, 2013). Innovation is an introduction to equipment, systems, laws, products or services, new production process technology, a new administrative structure or system, or a new planning program for an organization to adopt (Damanpour, 1991). The type of innovation is adoption behavior and the determining factors of the innovation (Damanpour \& Evan, 1984); Damanpour, 1991). Research by Damanpour (1991) classified innovations into several types, including administrative innovation, technical innovation, product/service innovation, process innovation, radical innovation, and incremental innovation.

Innovation is the main source of performance improvement because it allows companies to avoid competing primarily based on costs (Rosenbusch et al., 2011). However, the benefits of innovation require innovation output not only innovation efforts, which require costs in the short term so that it also affects performance (Lichtenthaler, 2016). Innovation plays an important role in creating value, such as penetrating new markets, maintaining existing market shares, and increasing competitive advantage. Innovation is an important element of corporate strategy. By having innovation, organizations have a strong weapon to win the competition. 
The purpose of innovation is not only to reduce costs, but also to improve the quality of products and services, to design better products, to extend product life cycles, and to respond to customer needs and demands. Also, innovation is very important for developing new products and services, new organizational models, and new marketing techniques.

\section{Management Accounting Information Systems (MAIS)}

Each strategy needs specific information that is different from the information needs of other strategies. Implementing an innovation strategy also requires certain information. Therefore, the innovation strategy influences the design of MAIS to produce the type of information needed by management. Otley (1980) revealed that the contingency approach can be used to analyze and design management accounting systems to provide information that can be used for various purposes that affect the better performance of internal processes. The results prove a contingency approach to management accounting systems states that there is no universal management accounting system that can be applied correctly for all organizations.

Companies that implement innovation strategies will continue to oversee the creation of market opportunities, commit to change, and respond quickly to competitors. Innovative companies also continually develop new market opportunities that require flexible and innovative structures. As a result, non-financial and future-oriented external information is needed by managers to make better decisions. Thus, the broad scope of information provided by management accounting systems will be very useful in decision making (Abernethy \& Guthrie, 1994).

\section{The Influence of Innovation Strategy and Company} Performance.

Research shows that companies must be more innovative to win the competition (Evangelista et al., 1998). Global competition forces companies to innovate by reducing production costs and increasing technological capabilities and product innovation. Companies need to manipulate the structure and organization of their work, improve core competencies, develop new structures to respond to new market conditions and customer demands, and set different markets, to enhance cooperation with other companies, and to invest in innovation (Ulusoy et al., 2001).

The influence of innovation on company performance indicators (customer satisfaction, productivity, and technological competitiveness) has been demonstrated by Terziovski (2002). The results of his research show that integrated innovation strategies have little effect on performance. Incremental innovation strategies are more appropriate to be used as incentives for sustainable innovation, while radical innovation strategies are more suitable for producing rapid changes in products and processes.

Innovation has a positive influence on performance based on the resource-based theory. Innovation is an important factor for a company to effectively compete in the domestic and global markets as well as an important component in the strategy of an organization (Davila, 2000). Companies with high innovation rates can build competitive advantage and achieve high performance (Hurley \& Hult, 1998; Davila, 2000; Weerawardena, 2003; Ratmono and Nahartyo, 2012). Previous research has empirically proven that high innovation will result in high company performance (Weerawardena, 2003; Bisbe \& Otley, 2004; Jankala, 2010). Many quantitative studies have shown a positive relationship between innovation and several measures of company performance (Rosenbusch et al., 2011; Anderson \& Potočnik, 2014; Ndubisi \& Capel, 2015; Lichtenthaler, 2016).

Based on the arguments above, the first hypothesis is:

H1: Innovation has a positive effect on company performance. 
The Role of Management Accounting Information Systems as an intervening variable between innovation and company performance.

Innovation strategies affect all aspects of an organization including information that must be provided by management accounting information systems. Bromwich (1990) argues that MAIS helps management to deal with competitive market challenges that focus on increasing the value-added of a company beyond its competitors and helping managers to monitor performance in a competitive environment. Correspondence between information and management accounting information systems will certainly improve the quality of decisions and improve overall organizational performance in terms of better internal process performance, customer performance, and financial performance (Gerloff et al., 1991).

Mia \& Chenhall (1994) shows that the characteristics of MAIS will improve organizational performance. Next, according to Chia (1995) high-level decentralization, broad characteristics of MAIS, aggregation, timeliness, and integration will enhance organizational performance as well. Mia \& Clarkef (1999) examine the relationship between the intensity of market competition, the use of MAIS, and firm performance. The results conclude that the use of information in the MAIS mediates the relationship between the intensity of market competition and firm performance. In Indonesia, research conducted by Musmini (2003) in manufacturing companies provides evidence that the use of information in MAIS is positively related to organizational performance. MAIS plays a role in the relationship between strategy selection and company performance (Chong \& Chong, 1997; Ajibolade, 2013). This study shows the broad scope of MAIS has a positive effect on performance. MAIS that covers the scope, timeliness, integration, and aggregation has a positive effect on company performance (Hammad et al., 2013; Al-mawali, 2013). Several studies have been conducted regarding the design of management accounting systems that are influenced by some environmental variables and organizational attributes, such as environmental uncertainty, technology, organizational size, etc. (Gordon \& Narayanan, 1984; Govindarajan, 1984). The results are still not consistent. Various research results can be attributed to variations in culture and inter-organizational strategy (Otley, 1980; Gani \& Jermias, 2006). Based on the previous arguments, the following hypothesis was developed:

H2: Management Accounting Information Systems mediates the effects of innovation and company performance.

\section{METHODS}

\section{Research Model}

Specific equation of the measurement model, where variables must be determined that measure the construct and determine a series of matrices that show hypothesized correlations between constructs. Based on the framework that has been stated in the previous section, the structural equation that will be tested for the coefficient is as follows:

a. Direct effect testing:

$\mathrm{CP}=\gamma_{1} \mathrm{I}+\xi_{1}$ (Model 1)

b. Testing through mediating variables:

$\mathrm{CP}=\gamma_{2} \mathrm{I}+\beta_{1} \mathrm{MAIS}+\xi_{2}$ (Model 2)

Notes:

$$
\begin{aligned}
& \mathrm{CP}=\text { Company Performance } \\
& \text { I }=\text { Innovation } \\
& \text { MAIS }=\text { Management Accounting Information }
\end{aligned}
$$

$\xi \quad=$ Model error

\section{Research design}

This research uses a quantitative approach through a survey method by distributing questionnaires to potential respondents. The instruments in this study refer to previous research. Although in previous 
studies the instrument has been tested for validity and reliability, this study will still test its validity and reliability because there is a possibility of differences in perceptions or changes in value for each question posed to the respondents. Respondents were asked to express their opinion about the constructs used in research which include innovation, MAIS, and company performance.

\section{Population and Sample Determination}

The population in this study is the manager/ supervisor of the business unit in an oil palm company in Riau Province totaling 43 companies. The unit of analysis of this study is the manager/ supervisor. The sampling method is an accidental sampling/convenience sampling. This technique is part of the non-probability sampling which was chosen because of its convenience and proximity to the researcher. The number of respondents obtained in this study was 28 managers/supervisors.

\section{Definition and Operations of Variables}

The variables in this study are classified as follows: (1) financial performance is the dependent variable (endogenous); (2) innovation is an independent variable (exogenous), (3) management accounting information system variable is a mediating variable (exogenous)

1. Company Performance, defined as respondents' perceptions of the company's financial and non-financial performance compared to competitors relative to the past 1 year. Measurement of this variable uses the dimensions of profitability, growth, and overall company performance (Hadjimanolis $\&$ Dickson, 2000). Company performance is measured based on respondents' perceptions in assessing their performance through indicators: sales growth, ROI (Return On Investment), and ROA (Return on Assets), and growth in the number of employees (employment growth). A Likert scale from 1 to 7 is used as a measure.

2. Innovation, defined as respondents' perceptions of their unique ways to achieve sustainable competitive advantage and excellent performance. Based on Damanpour (1991), innovation has four dimensions namely product innovation, process innovation, administrative innovation, and technological innovation. But in this study, the dimensions of product innovation were not tested because the population of this study produced a specific product namely CPO. The process innovation variable is measured using two indicators: input of raw materials, and production equipment. Administrative innovation is measured using indicators: organizational structure, administrative/ accounting processes. Technological innovation is measured using indicators: production technology and production process technology. A Likert scale from 1 to 7 is used as a measure.

3. MAIS is defined as respondents' perceptions about assessing the "level of use" of Management Accounting Information Systems in their daily decision-making activities by considering the characteristics of the information primarily to support the formulation of innovation and execution strategies. the measurement adopted the instrument developed by Chenhall \& Morris, (1986). It includes the following four aspects: (1) broad-scope, (2) aggregate, (3) integration, and (2) timeliness. Likert from 1 to 7 was used as a measure.

\section{Hypothesis testing}

SEM analysis with the PLS warp program version 2.00 was used to test the hypothesis. This statistical analysis tool was chosen because of several advantages (Hair et al., 2013; Kock, 2011). First, SEM-PLS is suitable for this research model that uses variables that cannot be measured directly (latent variables). Second, SEM analysis simultaneously multiple dependence as in this research model. Third, component-based SEM (PLS) can estimate highly complex models with small sample sizes.

The procedure for testing the MAIS as a mediating variable in the relationship between innovation and company performance is as follows (Hair et 
al., 2010):

1. Estimating the direct effect of an innovation strategy on performance (arrow c).

2. Estimating the indirect effect simultaneously with SEM-PLS where the innovation $\rightarrow$ company's performance (arrow c), innovation $\rightarrow$ MAIS (arrow a), MAIS $\rightarrow$ corporate performance (arrow b).

The mediation effect requirements must meet the following requirements: the coefficient $\mathrm{c}$ is significant in model 1 ; The coefficients $\mathrm{a}$ and $\mathrm{b}$ must be significant in model 2 . Conclusions based on the following

1. If the coefficient $\mathrm{c}$ from the estimation results of model 2 is still significant and does not change $(c "=c)$ then the mediation hypothesis is not supported

2. If the coefficient c decreases $(c "<c)$ but it is still significant, then the form of mediation is partial mediation.

3 . If the value of the coefficient $c$ decreases $(c "<c)$ but it is not significant, then the form of mediation is full mediation

\section{RESULTS AND DISCUSSION}

Respondent Response Rate

The population in this study is a palm oil company that produces $\mathrm{CPO}$ totaling 43 companies operating in Riau Province. A total of 100 questionnaires have been distributed to respondents via email and also sent directly to the location. 28 questionnaires returned and can be processed further. The response rate of this study is very low, only $28 \%$, but for research in Indonesia, the average survey response is 10\% -20\% (Kurnianigsih and Indrianto, 2001; Lau \& Sholihin, 2005).

\section{Result of Construct Validity and Reliability Testing} Convergent validity test in SEM-PLS uses Average Variance Extracted (AVE) (Kock, 2011). The results of the outer model in Table 1 indicate that the convergent validity criteria have been met with an AVE score of more than 0.50. Furthermore, the instrument reliability test has also been met with composite reliability and a Cronbach alpha of more than 0.60 .

The descriptive statistics of this research can be seen in the table 2.

Descriptive statistics in table 2 show the level of the innovation strategy is quite high with an average of 33.75 above the average value of the theoretical range of 32. The utilization of MAIS in the sample also shows a higher average value equal to 101.09 compared to the average value of the theoretical range of 80 . The table also shows that the company's

Table 1. Validity and Reliability Test

\begin{tabular}{lccc}
\hline \multirow{2}{*}{ Construct } & Validity & \multicolumn{2}{c}{ Reliability } \\
\cline { 2 - 4 } & AVE & $\begin{array}{c}\text { Composite } \\
\text { Reliability }\end{array}$ & Cronbach Alpha \\
\hline Innovation Strategy & 0.576 & 0.791 & 0.715 \\
\hline MAIS & 0.547 & 0.680 & 0.640 \\
\hline Company Performance & 0.551 & 0.813 & 0.719 \\
\hline
\end{tabular}

Source: Processed Data

Table 2. Descriptive Statistic

\begin{tabular}{lccccc}
\hline \multicolumn{1}{c}{ Construct } & Average & $\begin{array}{c}\text { Standard } \\
\text { Deviation }\end{array}$ & Median & $\begin{array}{c}\text { Theoretical } \\
\text { Range }\end{array}$ & Actual Range \\
\hline Innovation & 33,75 & 1,072 & 48 & $8-56$ & $8-56$ \\
\hline MAIS & 101,098 & 1,038 & 120 & $20-140$ & $20-140$ \\
\hline Company Performance & 26,14 & 1,134 & 30 & $6-42$ & $6-36$ \\
\hline
\end{tabular}

Source: Processed Data 
performance is also above the target displayed with an average of 26.14 , slightly higher than the theoretical range of the average value of 24 .

Table 3 shows descriptive data of the respondents grouped by gender, education, and length of work.

\section{Result}

The mediation model test results are shown in Table 4. PLS output as a result of the mediation test can be seen in Figure 1. The estimation results from model 1 and model 2 show that the goodness of fit criteria has been met where the APC and ARS values are statistically significant and the AVIF value is less than 5 (Kock, 2011). The results of table 4 show that the requirements of the mediation test have been met by the coefficients $c, a$, and b significantly with the respective values of $0.244,0.42$, and 0.58 .

Test results show the coefficient of the direct effect of innovation on performance (c) in model 1 is 0.244 and significant. The results of the estimation model 2 show the indirect effect of innovation on performance mediated by MAIS with the coefficient (c») decreased to 0.22 but still significant. This shows partial mediation or in other words, MAIS partially mediates the effect of innovation on performance. The form of partial mediation shows that the MAIS not only mediates the relationship between innovation on firm performance but there are other mediating factors (Baron \& Kenny, 1986). The results of testing support indicate the direction of hypotheses 1 and 2 is accepted where innovation affects directly or indirectly on company performance, MAIS act as a partial mediating effect of the relationship between innovation on company performance.

\section{Discussion}

Test results through SEM-PLS Warp 3 prove empirically against both direct and indirect models (through mediation). Hypothesis 1 states that innovation influences company performance. Global competition forces companies to innovate

Table 3. Descriptive Respondents

\begin{tabular}{|c|c|c|}
\hline \multicolumn{2}{|c|}{ Annotation } & \multirow{2}{*}{$\begin{array}{c}\text { Amount } \\
24\end{array}$} \\
\hline Gender & Male & \\
\hline & Female & 4 \\
\hline \multirow[t]{3}{*}{ Education } & Masters & 2 \\
\hline & Undergraduate & 25 \\
\hline & Diploma & 1 \\
\hline \multirow[t]{3}{*}{ Length of work } & 3 - 10 years & 15 \\
\hline & 11 - 20 years & 12 \\
\hline & 21 - 31 years & 1 \\
\hline
\end{tabular}

Source: Processed Data

Table 4. The results of Hypothesis 1 and Hypothesis 2 tests

\begin{tabular}{llccc}
\hline \multirow{2}{*}{ Route } & \multicolumn{2}{c}{ Direct Effect } & \multicolumn{2}{c}{ Indirect Effect } \\
\cline { 2 - 4 } & Coefficient & $p$-value & Coefficient & $p$-value \\
\hline Innovation $\rightarrow$ MAIS & & & 0,42 & 0,01 \\
\hline MAIS $\rightarrow$ Company Performance & & 0,58 & 0,01 \\
\hline Innovation $\rightarrow$ Company Performance & 0,244 & 0,01 & 0,22 & 0,1 \\
\hline Model FIT Indicator & & & 0,406 & 0,003 \\
\hline Average Path Coefficient (APC) & & & 0,322 & 0,014 \\
\hline Average R-square (ARS) & & 1,124 & \\
\hline Average Variance Inflation Factor (AVIF) & 1,000 & &
\end{tabular}

Source: Processed Data 


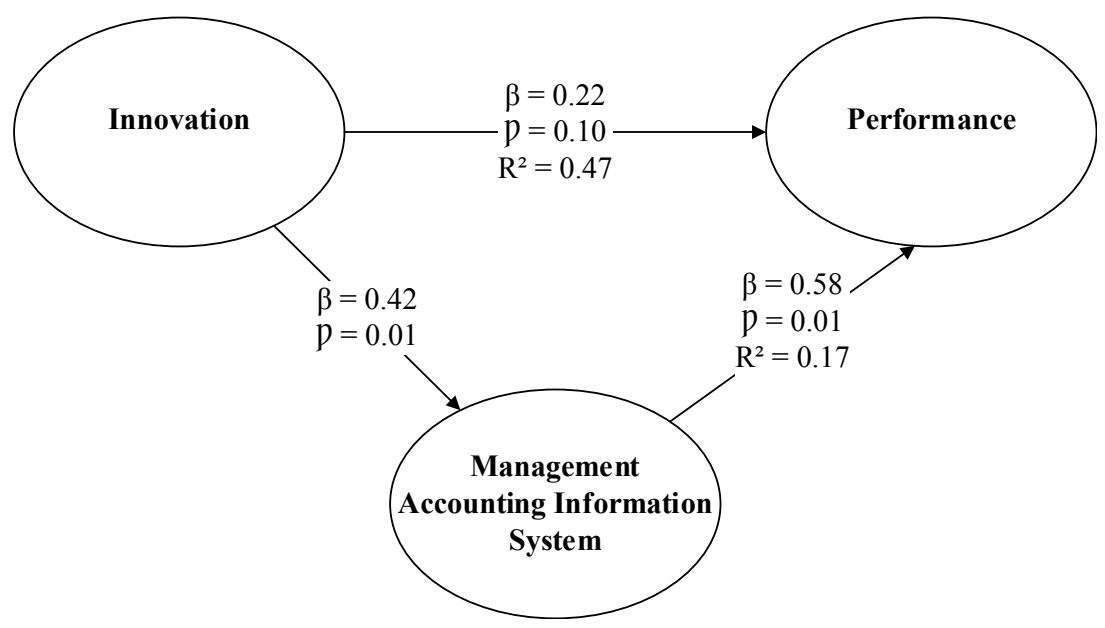

Figure 1. PLS Output Model

through process innovation, administrative innovation, and technological innovation that can drive companies by reducing production costs and enhancing technology capabilities that provide better company performance. Research by Evangelista et al. (1998), shows that companies must be more innovative to win the competition This study also supports research by Rosenbusch et al. (2011) where innovation is the main source of performance improvement because it allows companies to avoid competing primarily based on cost. Companies with high innovation can build competitive advantage and achieve high performance (Hurley \& Hult, 1998; Davila, 2000; Weerawardena, 2003, Ratmono and Nahartyo, 2012).

Hypothesis 2 states that MAIS mediates the effect of innovation and firm performance. The results showed that hypothesis 2 was also supported. Companies that implement innovation strategies will continue to oversee the creation of market opportunities, commit to change, and respond quickly to competitors. Innovative companies also continually develop new market opportunities that require flexible and innovative structures. As a result, non-financial and future-oriented external information is needed by managers to make better decisions. Thus, the broad scope of information provided by the MAIS will be very useful in decision making (Abernethy \& Guthrie, 1994). In addition to the broad scope, the timeliness of the delivery of information must also be a concern so that the possibility of losses can be avoided. MAIS will also be useful for managers in making decisions if it is integrated into all activities in the company. Aggregation in MAIS will support management to consider the impact that will occur on decisions that will be taken. So that the innovation strategy that will be decided by the management and through a good MAIS can improve company performance (Mia \& Chenhall, 1994; Chia, 1995; Mia \& Clarkef, 1999; Musmini, 2003).

\section{MANAGERIAL IMPLICATIONS}

The results of this study indicate that the company's innovation ability can improve company performance. Furthermore, with the better the Management Accounting Information Mystem, the level of use of MAIS for innovations carried out can be conveyed accurately through broad scope, aggregation, integration, and timeliness that can be used by company management to make decisions and have an impact on improving company performance.

\section{CONCLUSION}

The results of this study as a whole indicate that innovation plays an important role in improving company performance. The indirect effect of 
innovation that will affect the improvement of MAIS will support management decision making which will also be associated with increased performance.

There are several limitations to this study that may be of concern for future research. First, this study does not specifically classify companies based on the innovation strategy chosen by the company so that the results of this study are not too in-depth. For example, does the company implement a product, process, or technology strategy. Second, the response rate of this study is also relatively small, allowing a low level of generalization. Future studies are suggested to use a larger sample. Third, this study also only uses a sample of manufacturing companies that produce crude palm oil operating in Riau Province. So that the possibility of differences in culture, environment, and policies between regions will influence the company in determining the strategy to be used. Suggestions for future researchers are to add other variables that affect company performance. Third, this study used a cross-sectional survey design, thus it cannot confirm the causal relationship between variables. The causal interpretation of this study is only a theoretical framework. Future research may consider using longitudinal designs or laboratory experiments to ascertain causal effect relationships.

REFERENCES

Abdallah, A. A. J. (2014). The Impact of Using Accounting Information Systems on the Quality of Financial Statements Submitted to the Income and Sales Tax Department In Jordan. European Scientific Journal, 9(10), 41-48. https://doi.org/https://doi. org/10.19044/esj.2013.v9n10p\%25p

Abernethy, M. A., \& Guthrie, C. H. (1994). An Empirical Assessment of the Fit between Strategy and Management Information System Design. , Accounting and Finance, 34(2), 49-66. https://doi.org/https://doi.org/10.1111/j.1467-629X.1994.tb00269.x

Ajibolade, S. O. (2013). Management Accounting Systems Design and Company Performance in Nigerian Manufacturing Companies : A Contingency Theory Perspective. British Journal of Arts and Social Sciences, 14, 228-244. https://doi.org/ https://doi.org/10.1080/00014788.1997.9729553

Al-mawali, H. (2013). Performance Consequences of Management Accounting System Information Usage in Jordan. Business and Economic Horizons, 9(1), 48-57. https://doi.org/10.15208/beh.2013.3

Anderson, N., \& Potočnik, K. (2014). Innovation and Creativity in Organizations: A State-of-the-Science Review , Prospective Commentary, and Guiding Framework. Journal of Management, 40(5), 1297-1333. https://doi. org/10.1177/0149206314527128

Baron, R. M., \& Kenny, D. A. (1986). The Moderator-Mediator Variable Distinction in Social Psychological Research: Conceptual, Strategic, and Statistical Considerations. Journal of Personality and Social Psychology, 51(6), 1173-1182. https://doi. org/10.1037//0022-3514.51.6.1173

Bisbe, J., \& Otley, D. (2004). The Effects of the Interactive Use of Management Control Systems on Product Innovation. Accounting, Auditing \& Accountability Journal, 29, 709-737. https://doi.org/10.1016/j.aos.2003.10.010

Bromwich, M. (1990). The Case for Strategic Management Accounting: the Role of Accounting Information for Strategy in Competitive Markets. Accounting, Organizations, and Society, 15(1), 27-46. https://doi.org/10.1016/0361-3682(90)90011-I

Chenhall, R. H. (2003). Management Control Systems Design Within its Organizational Context: Findings from ContingencyBased Research and Directions for The Future. Accounting, Organizations and Society, 28, 127-168.

Chenhall, R. H., \& Morris, D. (1986). and Impact of Structure, Environment , and Interdependence on the Perceived Usefulness of Management Accounting Systems. American Accounting Association, 61(1), 16-35. Retrieved from http://www.jstor. org/stable/247520

Chia, Y. M. (1995). Decentralization, Management Accounting System (MAS) Information Characteristics and Their Interaction Effects on Managerial Performance. Journal of Business Finance \& Accounting, 22(6), 811-830. https://doi.org/https:// doi.org/10.1111/j.1468-5957.1995.tb00390.x 
Chong, V. K., \& Chong, K. M. (1997). Strategic Choices , Environment Uncertainty and SBU Performance : A Note on the Intervening Role of Management Accounting Systems. Accounting and Business Research, 27(4), 268-276. https://doi.or g/10.1080/00014788.1997.9729553

Damanpour, F. (1991). Organizational Innovation: A Meta-Analysis of Effects of Determinants and Moderators. The Academy of Management Journal, 34(3), 555-590. https://doi.org/DOI: 10.2307/256406

Damanpour, F., \& Evan, W. M. (1984). Organizational Innovation and Performance : The Problem of "Organizational Lag." Administrative Science Quarterly, 29(3), 392-409. https://doi.org/DOI: 10.2307/2393031

Davila, T. (2000). An Empirical Study on the Drivers of Management Control Systems' Design in New Product Development. Accounting, Organizations and Society, 25, 383-409. https://doi.org/10.1016/S0361-3682(99)00034-3

Davis, G. F., \& Cobb, J. A. (2010). Resource Dependence Theory : Past and future. Research in the Sociology of Organizations, 28, 21-42. https://doi.org/10.1108/S0733-558X(2010)0000028006

Evangelista, R., Sandven, T., Sirilli, G., \& Smith, K. (1998). Measuring Innovation in European Industry. International Journal of the Economics of Business, 5(3), 311-333. https://doi.org/http://dx.doi.org/10.1080/13571519884413

Gani, L., \& Jermias, J. (2006). Investigating the Effect of Board Independence on Performance Across Different Strategies. The International Journal of Accounting, 41, 295-314. https://doi.org/10.1016/j.intacc.2006.07.009

Gerloff, E. A., Muir, N. K., \& Bodensteiner, W. D. (1991). Three Components of Perceived Environmental Uncertainty: An Exploratory Analysis of the Effects of Aggregation. Journal of Management, 17(4), 749-768. https://doi.org/https://doi. org/10.1177/014920639101700408

Gordon, L. A., \& Narayanan, V. K. (1984). Management Accounting Systems Perceived Environmental Uncertainty and Organization Structure: an Empirical Investigation. Accounting, Organizations, and Society, 9(1), 33-47. https://doi. org/10.1016/0361-3682(84)90028-X

Govindarajan, V. (1984). Appropriateness of Accounting Data in Performance Evaluation: an Empirical Examination of Environmental Uncertainty as an Intervening Variable. Accounting, Organizations, and Society, 9(2), 125-135. https://doi. org/https://doi.org/10.1016/0361-3682(84)90002-3

Hadjimanolis, A., \& Dickson, K. (2000). Innovation Strategies of SMEs in Cyprus, a Small Developing Country. International Small Business Journal, 18(4), 62-79. https://doi.org/DOI: 10.1177/0266242600184004

Hair, J. F., Black, W. C., Babin, B. J., \& Anderson, R. E. (2013). Multivariate Data Analysis (Seventh Ed). Pearson New International Edition.

Hammad, S. A., Jusoh, R., \& Ghozali, I. (2013). Decentralization, Perceived Environmental Uncertainty, Managerial Performance and Management Accounting System Information in Egyptian Hospitals. International Journal of Accounting and Information Management, 21(4), 314-330. https://doi.org/10.1108/IJAIM-02-2012-0005

Helfert, Erich A. 1996. Teknik Analisis Keuangan. Jakarta: Erlangga.

Hurley, R. F., \& Hult, G. T. M. (1998). Innovation, Market Orientation, and Organizational Learning: An Integration and Empirical Examination. Journal of Marketing, 62(3), 42-54. https://doi.org/10.2307/1251742

Jankala, S, 2010, Role of Interactive Control Systems and Foresight in Competitive Dynamics of Business, A paper Presented in $33^{\text {th }}$ Europian Accounting Association (EAA) $33^{\text {th }}$, Istambul, Turki.

Jennings, P., \& Beaver, G. (1997). The Performance and Competitive Advantage of Small Firms: A Management Perspective. International Small Business Journal, 15(2), 63-75. https://doi.org/10.1177/0266242697152004

Jones, G. R. (2013). Organizational Theory, Design , and Change (Seventh Ed). Pearson.

Kaplan, R. S., 2009. Conceptual foundation s of the Balanced Scorecard. Handbook of Management Accounting Research, 3 , 1253-1269.

Kaplan, R. S., \& Norton, D. P., 2001. The Strategy-Focused Organization: how Balanced Scorecard companies thrive in the new business environment. Boston, MA: Harvard Business School Press.

Kock, N. (2011). Using WarpPLS in e-Collaboration Studies : Mediating Effects, Control and Second Order Variables, and Algorithm Choices. Nternational Journal of E-Collaboration, 7, 1-13. https://doi.org/10.4018/jec.2011070101

Langfield-smith, K. (2007). A Review of Quantitative Research in Management Control Systems and Strategy. In C. Chapman, A, Hopwood, and M. Shields (Eds.), Handbook in Management Accounting (Vol. 2). Oxford: Elsevier. https://doi.org/10.1016/ S1751-3243(06)02012-8

Lau, C. M., \& Sholihin, M. (2005). Financial and Nonfinancial Performance Measures : How Do They Affect Job Satisfaction? The British Accounting Review, 37, 389-413. https://doi.org/10.1016/j.bar.2005.06.002

Lichtenthaler, U. (2016). Toward an Innovation-based Perspective on Company Performance. Management Decision, 54(1), 66-87. https://doi.org/10.1108/MD-05-2015-0161

Mia, L., \& Chenhall, R. H. (1994). The Usefulness of Management Accounting Systems Functional Differentiation and Managerial Effectiveness. Accounting, Organizations and Society, 19(1), 1-13. https://doi.org/10.1016/0361-3682(94)90010-8

Mia, L., \& Clarkef, B. (1999). Market Competition, Management Accounting Systems and Business Unit Performance. Management Accounting Research, 10, 137-158. Retrieved from http://www.idealibrary.com 
Musmini, L.S., 2003. Pengaruh Intensitas Kompetisi Pasar dan Sistem Akuntansi Manajemen terhadap Kinerja Unit Bisnis. Thesis (tidak dipublikasikan), Program PascaSarjana UGM, Jogjakarta

Kurnianingsih, R, dan Indriantoro, Nur, 2001, Pengaruh Sistem Pengukuran Kinerja dan Sistem Penghargaan terhadap keefektifan TQM (Study Empiris pada Perusahaan Manufaktur di Indonesia), The Indonesian Journal of Accounting Research, Vol 4(1)

Ndubisi, N. O., \& Capel, C. M. (2015). Innovation Strategy and Performance of International Technology Services Ventures: The Moderating Effect of Structural Autonomy. Journal of Service Management, 26(4), 548-564. https://doi.org/10.1108/ JOSM-04-2015-0118

Otley, D. T. (1980). The Contingency Theory of Management Accounting: Achievement and Prognosis. Accounting, Organizations and Society, 5(4), 413-428. https://doi.org/https://doi.org/10.1016/0361-3682(80)90040-9

Perkebunan Sawit Riau Terluas di Indonesia. (2015). AntaraNews.com

Porter, M. E. (2008). Competitive Advantage: Creating and Sustaining Superior Performance. Simon and Schuster. Com.

Ratmono, Dwi. Nahartyo, Ertambang, 2012, Examining Mediating and Moderating Models on the Relationship Among Management Control System, Innovations, and Performance, The Indonesian Journal of Accounting Research, Vol. 15(1). DOI: http://doi.org/10.33312/ijar.249

Rosenbusch, N., Brinckmann, J., \& Bausch, A. (2011). Is innovation always beneficial? A Meta-Analysis of the Relationship Between Innovation and Performance in SMEs. Journal of Business Venturing, 26(4), 441-457. https://doi.org/10.1016/j. jbusvent.2009.12.002

Terziovski, M. (2002). Achieving Performance Excellence Through an Integrated Strategy of Radical Innovation and Continuous Improvement. Measuring Business Excellence, 6(2), 5-14. https://doi.org/10.1108/13683040210431419

Ulusoy, G., Kaylan, A. R., Bilgiç, T., \& Payzın, A. E. (2001). Technology Management Process of the Part and Component Suppliers in the Turkish Automotive Industry. Technology Management, 5(4), 245-260.

Van der Stede, W. A., Chow, C. W., \& Lin, T. W. (2006). Strategy, Choice of Performance Measures, and Performance. Behavioral Research in Accounting, 18, 185-205.

Weerawardena, J. (2003). The Role of Marketing Capability in Innovation-based Competitive Strategy. Journal of Strategic Marketing, 11(1), 15-35. https://doi.org/10.1080/0965254032000096766

Wild, Jhon. J, K. R. Subramanyam, 2010, Analisis Laporan Keuangan, Salemba Empat, Jakarta. 